\title{
Evaluation of physicochemical properties of anthocyanin extracts and powders from purple sweet potato (Ipomoea batatas L.)
}

\author{
Ekaputra, T. and *Pramitasari, R. \\ Department of Food Technology, Faculty of Biotechnology, Atma Jaya Catholic University of Indonesia, \\ Cisauk, Tangerang, Banten 15345, Indonesia.
}

Article history:

Received: 27 April 2020

Received in revised form: 6 June 2020

Accepted: 8 June 2020

Available Online: 18 August 2020

\section{Keywords:}

Anthocyanin,

Antioxidant,

Extraction,

Foam Mat Drying,

Purple sweet potato

DOI:

https://doi.org/10.26656/fr.2017.4(6).195

\begin{abstract}
Purple sweet potato (Ipomoea batatas L.) is one of the food commodities that contain anthocyanin. This research aimed to evaluate the physicochemical properties of anthocyanin extracts and powders from purple sweet potato. Purple sweet potato anthocyanin was extracted using a water solvent with the addition of citric acid in different concentrations $(0,2,4$, and $6 \mathrm{~g} / 100 \mathrm{~mL})$. Ethanol solvent was used as a control. Foam mat drying was performed using variations of egg white composition (10 and 20 $\mathrm{mg} / 100 \mathrm{~mL}$ ). The result showed that extraction using a water solvent with $2 \mathrm{~g} / 100 \mathrm{~mL}$ of citric acid was the most effective condition to obtain the highest total anthocyanin content $(\mathrm{p}<0.05)$. However, its total phenolic, flavonoid, and antioxidant activity were lower compared to others. Total anthocyanin content of foam mat dried purple sweet potato powder made from the citric acid-water extract was significantly higher than the powder made from the citric acid-ethanol extract $(\mathrm{p}<0.05)$. There was no effect in the total phenolic, flavonoid, viscosity, and yellowish-red color of the powder obtained from citric acid-water extract as the increase of egg white concentration. The use of $20 \mathrm{~g} / 100 \mathrm{~mL}$ egg white in both powders produced from citric acid-water and ethanol extracts resulted in higher total anthocyanins and solubilities than powders using $10 \mathrm{~g} / 100 \mathrm{~mL}$ egg white. The color of the powder obtained from citric acid-water extract had a lower brightness level and higher yellowish-red color intensity compared to the powder made from citric acidethanol extract.
\end{abstract}

\section{Introduction}

In recent years, the use of natural pigments is considering to substitute synthetic food colorants as the demand of consumers to natural, safer, and healthier food products (Martins et al., 2016). Anthocyanin is a natural pigment that responsible for the red, purple, and blue colorants in vegetables, fruits, and tubers ( $\mathrm{Li}$ et al., 2012; Fang, 2015; Liu et al., 2015). Anthocyanin is a water-soluble pigment that included in a group of flavonoid compounds. It is a glycoside of polyhydroxy and polymethoxy from 2-phenylbenzopyrylium (flavylium) derivates. It consists of two benzene aromatic rings combined with the heterocyclic ring contains an oxygen atom (Ma et al., 2020). Besides the potential as the food colorant (Albuquerque et al., 2020), anthocyanin has antioxidant activity from the hydrogen atom donation to radical compounds (Ma et al., 2020), which contribute to health benefits (Arevström et al., 2019; Guo et al., 2020; Peng et al., 2020).
Purple sweet potato (Ipomoea batatas L.) is one type of tuberous roots originated from South America, belongs to Convolvulaceae family, and usually grows in tropics and some warm temperate regions. The tuberous roots become fleshy and enlarged because of carbohydrates as food reserves (Levetin and McMahon, 2012). Other than that, purple sweet potato contains anthocyanin. Based on previous research, total anthocyanin content in purple sweet potatoes ranged between 51.5 - $174.7 \mathrm{mg} / 100 \mathrm{~g}$ (Steed and Truong, 2008). The use of anthocyanin as the natural food ingredient can be obtained through an extraction process (He et al., 2015; Sinela et al., 2017; Chen et al., 2019). Maceration was used in this research to obtain the purple sweet potato anthocyanin. Maceration is a method of extraction with the soaking of the sample in a solvent to get certain compounds with the help of agitation (Mukherjee, 2019). This method is very simple, easy, and suitable for anthocyanin extraction (Azwanida, 2015; Puspawati et al., 2018; Zhang et al., 2018). 
The color stability of anthocyanin extract depends on the $\mathrm{pH}$ condition (Jiang et al., 2018). A previous study has reported that anthocyanin of purple sweet potato extract was stable and gave a red color at $\mathrm{pH}$ 1-3 due to the presence of the red flavylium cation. Meanwhile, $\mathrm{pH}$ 3-7 of the extract caused the hydration of the flavylium cation, which leads to a reduction of the red color intensity to pink, violet, and blue color. In this stage, the purple quinoidal anhydrase is dominant. At $\mathrm{pH}>8$, formation the carbinol and chalcone was occurred due to the opening of the central pyran ring, allowing the production of green to yellow color (Pham et al., 2019)

The use of ethanol at low $\mathrm{pH}$ has been widely chosen to extract anthocyanin since it has been known to obtain the optimum of anthocyanin content. Cai et al. (2016) have reported the optimum number of purple sweet potato anthocyanin extracted using $80 \%$ ethanol acidified with $0.05 \% \mathrm{HCl}$ was $2.08 \pm 7.24 \mathrm{mg} / \mathrm{g}$. However, the use of ethanol is often doubtful due to the halal issue (Alzeer and Hadeed, 2016). Therefore, water or acidified water can be an alternative in anthocyanin extraction to obtained safer extract (Park et al., 2010; Xu et al., 2015).

The degradation of anthocyanin extract occurred during about two weeks of storage (Sinela et al., 2017; Achir et al., 2019; Chen et al., 2019). Anthocyanin degradation increased as increasing water content and water activity. Increased water will make increasing of molecular water diffusion and mobility in the anthocyanin molecules, thereby increasing the degradation reaction (Aguidelo-Lavarde et al., 2013; Lavelli and Kerr, 2019). Storage of foam mat dried anthocyanin powder has been reported to maintain color stability and the number of anthocyanin content (Tavares et al., 2020).

Foam mat drying is one type of drying process where the liquid is whipped into foams and then dried. This method is suitable for a heat-sensitive compound like anthocyanin. Another of its advantages because of simplicity, rapid drying, and cost-effectiveness (Hardy and Jideani, 2017). The foam mat drying process can retain the nutritional content and produce the porous form of the powder that has a good solubility when reconstituted (Iqbal et al., 2018). To get the excellent physicochemical properties of the powder, the foaming agent is a critical key to success in the foam mat drying. Abbasi and Azizpour (2016) have reported that the level of the foaming agent affected the physicochemical properties of foam dried sour cherry powder.

Many studies about anthocyanin extraction and foam mat drying have been reported, but they are still fragmented. There is no information about anthocyanin extraction of purple sweet potato using a halal solvent followed by foam mat drying to obtain the excellent physicochemical properties of the powder, especially in total anthocyanin content. Hence, it is essential to get anthocyanin extract from purple sweet potato in a suitable extraction condition, which is guaranteed to be safe and halal. The use of egg white as a foaming agent in the foam mat drying process needs to be optimized. Subsequently, this study aimed to evaluate the physicochemical properties of anthocyanin extracts and foam mat dried purple sweet potato powders.

\section{Materials and methods}

\subsection{Materials and sample preparation}

Commercial Japanese purple sweet potato (Dori) was purchased from the AEON supermarket, Banten, Indonesia. The purple sweet potato was peeled, washed, and mashed with the food processor. The sample was kept in the dark, airtight container in the refrigerator at $4^{\circ} \mathrm{C}$ for four days before analysis.

\subsection{Chemicals and reagents}

The commercial citric acid (Koepoe koepoe), carboxymethyl cellulose (CMC) (Koepoe koepoe), distilled water (Amidis), and liquid egg white were purchased from a local market in Banten, Indonesia. Maltodextrin DE 10-12 was purchased from Cipta Jaya Chemical, Indonesia. Other chemicals required in this study, including gallic acid, quercetin, ascorbic acid, and 2,2-diphenyl-1-picrylhydrazyl (DPPH) radical (SigmaAldric), Follin-Ciocalteu (Chem-mix Pratama, Indonesia). Potassium chloride $(\mathrm{KCl})$, sodium acetate $\left(\mathrm{CH}_{3} \mathrm{COONa}\right)$, sodium carbonate $\left(\mathrm{Na}_{2} \mathrm{CO}_{3}\right)$, potassium acetate $\left(\mathrm{CH}_{3} \mathrm{COOK}\right)$, aluminum chloride $\left(\mathrm{AlCl}_{3}\right)$, and ethanol (analytical grade) were obtained from Atma Jaya Laboratory.

\subsection{Anthocyanin extraction}

Anthocyanin extraction was carried out using the remaceration method at $25^{\circ} \mathrm{C}$ for $48 \mathrm{hrs}$ using distilled water with the addition of citric acid in different concentrations $(2,4,6,8 \mathrm{~g} / 100 \mathrm{~mL})$. A control was performed by using $96 \%$ ethanol solvent. A total of 10 $\mathrm{g} / 100 \mathrm{~mL}$ samples was macerated using an orbital shaker (GFL 3017, Germany) at $150 \mathrm{rpm}$ for $48 \mathrm{hrs}$. Then the solution was centrifuged at $3220 \times \mathrm{g}$ for $15 \mathrm{mins}$ to obtain the extract and precipitated the residue. The extract was filtered, and solvents were rotary evaporated (BUCHI R-300, Germany) at $45^{\circ} \mathrm{C}$ for ethanol and $55^{\circ} \mathrm{C}$ for water until the extract concentrated. The $\mathrm{pH}$ was measured using a $\mathrm{pH}$ meter (Mettler Toledo Five Easy F20) in each of the extracts. The extract then stored at $4^{\circ} \mathrm{C}$ refrigerator in the dark condition for further analysis (Ferarsa et al., 2018). 


\subsection{Anthocyanin drying}

Anthocyanin drying was performed with the foam mat drying method. A total of $100 \mathrm{~mL}$ concentrated extract of anthocyanin after evaporation was prepared, then $2 \mathrm{~g} / 100 \mathrm{~mL}$ of $1 \%(\mathrm{w} / \mathrm{v}) \mathrm{CMC}, 10 \mathrm{~g} / 100 \mathrm{~mL}$ maltodextrin, and egg white with the variation in concentrations of $10 \mathrm{~g}$ and $20 \mathrm{~g} / 100 \mathrm{~mL}$ were added. Afterwards, the mixture was stirred with mixer at high speed for 5 mins until all of the liquid becomes foam, then the foam was poured with $1 \mathrm{~cm}$ thickness. The foam was dried using oven dryer (Memmert UN 110, Germany) at $55^{\circ} \mathrm{C}$ for overnight and sieved with 60 Mesh sieve shaker. Anthocyanin powder was stored at $20^{\circ} \mathrm{C}$ in tightly closed and airtight conditions for further analysis (Abbasi and Azizpour, 2016).

\subsection{Chemical analyses}

\subsubsection{Total anthocyanin content}

The total anthocyanin content was measured using the $\mathrm{pH}$ differential method, according to Giusti and Wrolstat (2005) and Belwal et al. (2016). Briefly, the sample was mixed with $0.025 \mathrm{~mol} / \mathrm{L} \mathrm{KCl}$ buffer $\mathrm{pH} 1.0$ and $0.4 \mathrm{~mol} / \mathrm{L} \mathrm{CH}_{3} \mathrm{COONa}$ buffer $\mathrm{pH} 4.5$ with a ratio of 1:9 $(1 \mathrm{~mL}$ and $9 \mathrm{~mL})$ and $1: 1(1 \mathrm{~mL}$ and $1 \mathrm{~mL})$ for anthocyanin extract and powder, respectively. The absorbance was measured at 520 ( $\lambda_{\max }$ of anthocyanin) and $700 \mathrm{~nm}$. It was using a UV-Vis spectrophotometer (Thermo Scientific, USA) with distilled water as a blank. Absorbance (A) was calculated by Equation (1):

$\mathrm{A}=\left[\left(\mathrm{A}_{\lambda \max }-\mathrm{A}_{700 \mathrm{~nm}}\right) \mathrm{pH} 1.0\right]-\left[\left(\mathrm{A}_{\lambda \max }-\mathrm{A}_{700 \mathrm{~nm}}\right)\right.$ $\mathrm{pH}$ 4.5]

The reading of anthocyanin absorbance at $\lambda_{\max }$ needs to subtracted with absorbance at $\lambda=700 \mathrm{~nm}$ to ensured that the absorbance (A) of anthocyanin was precision without the disturbance from other materials since there was no absorbance of anthocyanin that occurred at $\lambda=$ $700 \mathrm{~nm}$.

Total anthocyanin content was calculated by Equation (2) as mg cyanidin-3-glucoside (C3G) equivalent per $\mathrm{g}$ dried weight of purple sweet potato:

$$
\text { Total anthocyanin }(m g / L)=\frac{\mathrm{A}_{\mathrm{N}} \mathrm{MW} \times \mathrm{DF} \times 1000}{\varepsilon \times \mathrm{L}}
$$

Where MW $=$ molecular weight of C3G $(449.2 \mathrm{~g} /$ $\mathrm{mol}), \mathrm{DF}=$ dilution factor, $1000=$ conversion factor from $\mathrm{g}$ to $\mathrm{mg}, \varepsilon=\mathrm{C} 3 \mathrm{G}$ molar absorptivity $(26900 \mathrm{~L} /$ mol.cm), and $\mathrm{L}=$ cell path length $(1 \mathrm{~cm})$.

\subsubsection{Total phenolic content}

The total phenolic content was determined using the Folin-Ciocalteu method with a gallic acid standard curve at the concentration of $50,75,100,125$, and $150 \mathrm{mg} / \mathrm{L}$ in distilled water (Cindrić et al., 2011; Belwal et al., 2016). A total of $0.5 \mathrm{~mL}$ sample was dissolved in $4.5 \mathrm{~mL}$ of distilled water, then $0.5 \mathrm{~mL}$ of $10 \%(\mathrm{v} / \mathrm{v})$ phenol FolinCiocalteu reagent was added and incubated for 5 mins. Afterward, $1.5 \mathrm{~mL}$ of $20 \%(\mathrm{w} / \mathrm{v}) \mathrm{Na}_{2} \mathrm{CO}_{3}$ was added to form a blue complex and incubated again for 90 mins. The absorbance was measured at $765 \mathrm{~nm}$ with distilled water was used as a blank. Total phenolic content was calculated as $\mathrm{mg}$ gallic acid equivalent (GAE) per $\mathrm{g}$ dried weight of purple sweet potato.

\subsubsection{Total flavonoid content}

The total flavonoid content was analyzed using the $\mathrm{AlCl}_{3}$ colorimetric method with a quercetin standard curve at the concentration level of 10,20,30,40, and 50 $\mathrm{mg} / \mathrm{L}$ in distilled water potato (Belwal et al., 2016; Cai et al., 2016). A total of $0.5 \mathrm{~mL}$ sample was dissolved in 1.5 $\mathrm{mL}$ of distilled water, then $0.5 \mathrm{~mL}$ of $10 \%(\mathrm{w} / \mathrm{v}) \mathrm{AlCl}_{3}$ was added. Afterward, $0.1 \mathrm{~mL}$ of $\mathrm{CH}_{3} \mathrm{COOK}$ and $2.8 \mathrm{~mL}$ of distilled water were added and incubated for 30 mins. The absorbance was measured at $415 \mathrm{~nm}$ with distilled water as a blank. Total flavonoid content was calculated as $\mathrm{mg}$ quercetin equivalent (QE) per $\mathrm{g}$ dried weight of purple sweet.

\subsubsection{Antioxidant activity}

Antioxidant activity was analyzed using the DPPH method, according to Marinova and Batchvarov (2011). Sample absorbance was measured by adding a $150 \mu \mathrm{L}$ sample with $1350 \mu \mathrm{L}$ of $96 \%$ ethanol and $1.5 \mathrm{~mL}$ of 0.06 $\mathrm{mmol} / \mathrm{L}$ DPPH solution. Control absorbance was measured by adding $1.5 \mathrm{~mL}$ of $96 \%$ ethanol with $1.5 \mathrm{~mL}$ of $0.06 \mathrm{mmol} / \mathrm{L}$ DPPH solution. Afterward, all of the solutions were incubated for 30 mins. The absorbance was measured at $517 \mathrm{~nm}$, with $96 \%$ ethanol was used as a blank. The calculation of antioxidant activity calculated by Equation (3)

Antioxidant activity $(\%)=\left[\frac{\left(A_{\text {control }}-A_{5 x m p l e}\right)}{A_{\text {control }}}\right] \times 100 \%$

\subsection{Physical analyses}

\subsubsection{Water content}

The water content of the anthocyanin powder was measured, according to Yaméogo et al. (2011). A total of $1 \mathrm{~g}$ anthocyanin powder was put into a weighed petri dish (initial weight), then dried in the oven dryer at $105^{\circ} \mathrm{C}$ for $2 \mathrm{hrs}$. Afterward, the petri dish was moved into desiccator for $1 \mathrm{hr}$ and finally weighed. The water content was calculated by Equation (4):

Water content $(\%)=\frac{\text { Initial weight }- \text { final weight }}{\text { sample wright }} \times 100 \%$ 


\subsubsection{Water activity}

A total of $5 \mathrm{~g}$ anthocyanin powder was put into a small petri dish. The water activity was determined using water activity $\left(\mathrm{A}_{\mathrm{w}}\right)$ meter $\left(\mathrm{AQUALAB}^{\circledR} 4 \mathrm{TE}, \mathrm{USA}\right)$ at $25^{\circ} \mathrm{C}$ (Zhu and Sun, 2019).

\subsubsection{Solubility}

The solubility of the powder was carried out, as described by Jivan et al. (2014). A total of $5 \mathrm{~g}$ anthocyanin powder was dissolved in $100 \mathrm{~mL}$ water and shaken at $2500 \mathrm{rpm}$ for $1 \mathrm{~min}$ on a vortex. The solution was centrifuged at $1811 \times \mathrm{g}$ for $5 \mathrm{mins}$, and then the supernatant was put into a weighed petri dish and dried in the oven dryer at $105^{\circ} \mathrm{C}$ overnight. The petri dish was weighed, then the solubility was calculated by Equation (5):

Solubility $(\%)=\frac{\text { Weight of solid in supematant }}{\text { Sample weight }} \times 100 \%$

\subsubsection{Viscosity}

The viscosity of powder was measured, according to Ekpong et al. (2016). A total of $5 \mathrm{~g}$ anthocyanin powder was dissolved in $100 \mathrm{~mL}$ water $(5 \% \mathrm{w} / \mathrm{v})$. The dial reading number was measured using a viscometer (Brookfield LVT 230, USA). Viscosity was calculated by Equation (6):

Viscosity $(\mathrm{mPa} . \mathrm{s})=$ Dial reading number $\mathrm{x}$ factor (spindle number 61 at $30 \mathrm{rpm}$ )

\subsubsection{Color}

A total of $5 \mathrm{~g}$ anthocyanin powder was put into a small petri dish. The brightness level $\left(\mathrm{L}^{*}\right)$, red $\left(\mathrm{a}^{*}\right)$, yellow $\left(b^{*}\right)$ color intensity, hue $\left(h^{*}\right)$, and chroma $\left(\mathrm{C}^{*}\right)$ of the powder were measured using Portable Colorimeter (NH301, China) at $25^{\circ} \mathrm{C}$. The values were standardized with a white plate (Steed and Truong, 2008; Ekpong et al., 2016).

Table 1. Chemical properties of anthocyanin extracts

\begin{tabular}{ccccccc}
\hline Solvent & $\begin{array}{c}\text { Citric acid } \\
(\mathrm{g} / 100 \mathrm{~mL})\end{array}$ & $\mathrm{pH}$ & $\begin{array}{c}\text { Total anthocyanin } \\
\text { content }(\mathrm{mg} / \mathrm{g})\end{array}$ & $\begin{array}{c}\text { Total phenolic } \\
\text { content }(\mathrm{mg} \mathrm{GAE} / \mathrm{g})\end{array}$ & $\begin{array}{c}\text { Total flavonoid } \\
\text { content }(\mathrm{mg} \text { QE/g) }\end{array}$ & $\begin{array}{c}\text { Antioxidant activity } \\
(\%)\end{array}$ \\
\hline \multirow{6}{*}{ Water } & 0 & 4.72 & $1.78 \pm 0.35^{\mathrm{e}}$ & $13.24 \pm 0.01^{\mathrm{d}}$ & $9.62 \pm 0.11^{\mathrm{c}}$ & $64.54 \pm 2.16^{\mathrm{a}}$ \\
& 2 & 2.01 & $5.23 \pm 0.07^{\mathrm{a}}$ & $12.81 \pm 0.01^{\mathrm{f}}$ & $7.65 \pm 0.29^{\mathrm{f}}$ & $57.72 \pm 4.93^{\mathrm{b}}$ \\
& 4 & 1.82 & $4.61 \pm 0.23^{\mathrm{b}}$ & $13.13 \pm 0.03^{\mathrm{d}}$ & $8.98 \pm 0.26^{\mathrm{d}}$ & $29.32 \pm 0.78^{\mathrm{e}}$ \\
& 6 & 1.71 & $4.58 \pm 0.19^{\mathrm{b}}$ & $12.99 \pm 0.06^{\mathrm{e}}$ & $9.60 \pm 0.40^{\mathrm{c}}$ & $4.77 \pm 0.29^{\mathrm{g}}$ \\
& 0 & 7.86 & $3.67 \pm 0.04^{\mathrm{c}}$ & $14.99 \pm 0.10^{\mathrm{a}}$ & $29.62 \pm 0.15^{\mathrm{a}}$ & $63.18 \pm 0.24^{\mathrm{a}}$ \\
Ethanol & 2 & 3.21 & $3.87 \pm 0.06^{\mathrm{c}}$ & $12.94 \pm 0.08^{\mathrm{e}}$ & $6.34 \pm 0.11^{\mathrm{g}}$ & $48.63 \pm 0.97^{\mathrm{c}}$ \\
& 4 & 2.94 & $3.56 \pm 0.32^{\mathrm{c}}$ & $13.37 \pm 0.00^{\mathrm{c}}$ & $8.21 \pm 0.02^{\mathrm{e}}$ & $38.64 \pm 0.39^{\mathrm{d}}$ \\
& 6 & 2.77 & $2.41 \pm 0.07^{\mathrm{d}}$ & $14.04 \pm 0.01^{\mathrm{b}}$ & $12.75 \pm 0.00^{\mathrm{b}}$ & $12.73 \pm 2.01^{\mathrm{f}}$ \\
\hline
\end{tabular}

Values were expressed as mean \pm S.D. Different superscripts in the same column indicate significantly different at $\mathrm{p}<0.05$
All analyses were done in duplicate. One-way analysis of variance (ANOVA) was performed on the statistical data analysis using IBM SPSS Statistics 24. Further statistical analysis of significant differences was performed by Duncan Test at $\mathrm{p}<0.05$.

\section{Results and discussion}

\subsection{Chemical properties of anthocyanin extract}

Ethanol has been known to effectively extracted the total anthocyanin content as its lysis ability on the vacuole membrane and enhance osmosis efficiency. A previous study has revealed that the total anthocyanin content in the purple sweet potato, which extracted using citric acid-ethanol solvent $(0.83 \mathrm{mg} / \mathrm{g})$, was higher than the citric acid-water solvent $(0.17 \mathrm{mg} / \mathrm{g})$ (Chen et al., 2019). Interestingly, total anthocyanin and flavonoid contents extracted with citric acid-water in this study were higher significantly $(\mathrm{p}<0.05)$ than citric acidethanol, as shown in Table 1. This finding gives useful information about the cost-effectiveness of the optimum extraction condition since water is cheaper than ethanol. Agrees with Halee et al. (2018), water has been able to extract higher anthocyanin content compared to ethanol in black rice bran. It might be due to the lower viscosity of water rather than ethanol $(0.89 \mathrm{cps}$ and $1.07 \mathrm{cps}$, respectively) that increased the efficiency of extraction as it could be more dispersed into the sample and dissolved anthocyanin and flavonoid contents (Alam et al., 2018).

The highest of total anthocyanin content was obtained by extraction using water with $2 \mathrm{~g} / 100 \mathrm{~mL}$ of citric acid. The addition of $2 \mathrm{~g} / 100 \mathrm{~mL}$ citric acid produced a $\mathrm{pH}$ value of 2.01. Based on Lu et al. (2010), the optimum of total anthocyanin content has been obtained from extraction using acidified water at $\mathrm{pH}<3$, since it made anthocyanin a stable flavylium cation form. However, the use of a higher concentration of acid caused partial hydrolysis of anthocyanin, which 
decreased in anthocyanin content (Abou-Arab et al., 2011).

The total phenolic content in the citric acid-ethanol extract was significantly higher $(\mathrm{p}<0.05)$ than in citric acid-water. This finding is a contradiction with the anthocyanin and flavonoid content, which was higher in citric acid-water than citric acid-ethanol extract since anthocyanin and flavonoid included in the group of phenolic compound. It might be due to the purple sweet potato used in this study likely contain other phenolic components that extracted more effectively using ethanol, as have been revealed in previous studies (Jung, 2011; Musilová et al., 2017; Meng et al., 2019).

Although the increase in citric acid concentration increases the number of total phenolic and flavonoid contents, still the extract without the addition of citric acid in both types of solvent produced higher total phenolic and flavonoid contents compared to those added with acid citric. This finding agrees with research by Halee et al. (2018). The phenolic component of purple sweet potato consists of two forms, which are free and bound. Free-form phenolics can be extracted well using acidified organic solvents. Meanwhile, the boundform phenolics can be extracted using acid or base hydrolysis. Thus it can be extracted well without the addition of acid (Gao et al., 2017; Meng et al., 2019).

The antioxidant activity of the extracts showed an upward trend as the increase in total anthocyanin content. Anthocyanin has antioxidant activity due to the facilitation of electron donor capacity or donation of the hydrogen atom (Ma et al., 2020). According to Sun et al. (2018), purple sweet potato has peonidin and cyanidinbased anthocyanins, which have high antioxidant activity compared to other types of anthocyanins. A high value of antioxidant activity was obtained in a sample containing lower anthocyanin but had the highest of the total phenolic and flavonoid contents as well. This finding is due to the role of phenolic and flavonoid, which also contributes to increasing antioxidant activity (Dovene et al., 2019).

\subsection{Chemical properties of anthocyanin powder}

Anthocyanin powder was obtained using a foam mat drying process from anthocyanin extracted with the addition of $2 \mathrm{mg} / 100 \mathrm{~mL}$ citric acid as the optimum extraction condition due to the total anthocyanin content. According to Table 2, total anthocyanin content in the powder made from water extract was significantly higher $(p<0.05)$ than ethanol extract. This value is in line with the total anthocyanin content in the extract before the drying process. The use of $20 \mathrm{~g} / 100 \mathrm{~mL}$ egg white as a foaming agent has significantly reduced the total anthocyanin content than the use of $10 \mathrm{~g} / 100 \mathrm{~mL}$ egg white in both extracts. It might be due to the dilution effect of anthocyanin as the increase in the number of egg white (Abbasi and Azizpour, 2016). The total anthocyanin, phenolic, and flavonoid contents in all powders decreased compared to extract. It occurred due to degradation of the phenolics compound during heating (Abbasi and Azizpour, 2016) and the effect of dilution of the components due to the addition of other materials in making foam such as egg whites, CMC, and maltodextrin.

Increasing the egg white caused increased antioxidant activity in both samples. It might be due to changing bioactivity of protein in the egg white during drying, which produced antioxidant activity (Wang et al., 2018). Antioxidant activity was affected by total phenolic and flavonoid contents as well. Buljat et al. (2019) have stated that some polyphenols and antioxidants that extracted using ethanol were able to bind the proteins and form the stable complexes, which affected their physiological properties, including antioxidant activity.

\subsection{Yield and physical properties of anthocyanin powders}

An increase in egg white concentration increased the yield of the powders, as seen in Table 3 . This finding is in line with Haryanto (2016), which reported that an increase in egg white concentration could increase the yield of mangosteen peel powder because of an increase in total solid of egg white. The yield of the powder from ethanol extract was lower than the water extract. Ethanol could decrease surface tension that formed the unstable transient foam. The drying of unstable foam resulted in reducing the total solids of powder (Hardy and Jideani, 2017).

Table 2. Chemical properties of anthocyanin powders

\begin{tabular}{lccccc}
\hline \multicolumn{1}{c}{ Solvent } & $\begin{array}{c}\text { Egg white } \\
(\mathrm{g} / 100 \mathrm{~mL})\end{array}$ & $\begin{array}{c}\text { Total anthocyanin } \\
\text { content }(\mathrm{mg} / \mathrm{g})\end{array}$ & $\begin{array}{c}\text { Total phenolic content } \\
(\mathrm{mg} \text { GAE/g) }\end{array}$ & $\begin{array}{c}\text { Total flavonoid } \\
\text { content }(\mathrm{mg} \text { QE/g) }\end{array}$ & $\begin{array}{c}\text { Antioxidant activity } \\
(\%)\end{array}$ \\
\hline Water and $2 \mathrm{~g} / 100 \mathrm{~mL}$ & 10 & $0.17 \pm 0.00^{\mathrm{a}}$ & $6.65 \pm 0.15^{\mathrm{b}}$ & $0.78 \pm 0.02^{\mathrm{b}}$ & $53.12 \pm 0.12^{\mathrm{c}}$ \\
citric acid & 20 & $0.16 \pm 0.00^{\mathrm{b}}$ & $6.51 \pm 0.10^{\mathrm{b}}$ & $0.74 \pm 0.02^{\mathrm{b}}$ & $59.76 \pm 0.23^{\mathrm{b}}$ \\
& 10 & $0.07 \pm 0.00^{\mathrm{c}}$ & $6.53 \pm 0.00^{\mathrm{b}}$ & $1.31 \pm 0.03^{\mathrm{a}}$ & $88.94 \pm 1.90^{\mathrm{a}}$ \\
Ethanol and $2 \mathrm{~g} / 100$ & 20 & $0.04 \pm 0.00^{\mathrm{d}}$ & $7.27 \pm 0.02^{\mathrm{a}}$ & $1.30 \pm 0.02^{\mathrm{a}}$ & $90.35 \pm 2.19^{\mathrm{a}}$ \\
\hline \begin{tabular}{l} 
mL citric acid \\
\hline
\end{tabular}
\end{tabular}

Values were expressed as mean \pm S.D. Different superscripts in the same column indicate significantly different at $\mathrm{p}<0.05$ 
Table 3. Yield and physical properties of anthocyanin powders

\begin{tabular}{lcccccc}
\hline \multicolumn{1}{c}{ Solvent } & $\begin{array}{c}\text { Egg white } \\
(\mathrm{g} / 100 \mathrm{~mL})\end{array}$ & Yield (\%) & Water content (\%) & Water activity & Solubility (\%) & Viscosity (mPa.s) \\
\hline Water and $2 \mathrm{~g} / 100 \mathrm{~mL}$ & 10 & $8.74 \pm 2.41^{\mathrm{ab}}$ & $5.47 \pm 0.13^{\mathrm{a}}$ & $0.27 \pm 0.00^{\mathrm{b}}$ & $80.26 \pm 2.17^{\mathrm{a}}$ & $6.40 \pm 0.57^{\mathrm{a}}$ \\
citric acid & 20 & $11.86 \pm 1.15^{\mathrm{a}}$ & $3.08 \pm 0.40^{\mathrm{b}}$ & $0.30 \pm 0.00^{\mathrm{a}}$ & $75.92 \pm 0.69^{\mathrm{b}}$ & $6.00 \pm 0.00^{\mathrm{a}}$ \\
Ethanol and $2 \mathrm{~g} / 100$ & 10 & $5.52 \pm 0.61^{\mathrm{c}}$ & $3.51 \pm 0.07^{\mathrm{b}}$ & $0.24 \pm 0.01^{\mathrm{c}}$ & $82.26 \pm 0.03^{\mathrm{a}}$ & $6.60 \pm 0.57^{\mathrm{a}}$ \\
mL citric acid & 20 & $7.92 \pm 0.11^{\mathrm{b}}$ & $2.38 \pm 0.02^{\mathrm{c}}$ & $0.27 \pm 0.00^{\mathrm{b}}$ & $78.98 \pm 0.53^{\mathrm{ab}}$ & $6.00 \pm 0.00^{\mathrm{a}}$ \\
\hline
\end{tabular}

Values were expressed as mean \pm S.D. Different superscripts in the same column indicate significantly different at $\mathrm{p}<0.05$

The water content of powders can be seen in Table 3 . The higher the egg white concentration was used, the lower the water content was obtained. An increase in egg white could increase the surface area of the foam. Thus, water evaporation occurred faster passed the foam layers during the foam mat drying process resulted in the lower water content (Abbasi and Azizpour, 2016; Hardy and Jideani, 2017).

Water activity determined the food product shelf life since the higher water activity can support the microorganism's growth and biochemical reactions (Nawi et al., 2015). Based on the analysis (Table 3), the water activity of the powders was low, which means it was microbiologically stable because of the values less than 0.60 . The increase in egg white concentration increased the water activity value. It caused by amphiphilic albumin in egg white tends to re-absorb water after going through a drying process (Hardy and Jideani, 2017).

Based on the solubility analysis (Table 3), the powders yielded good solubility. The addition of maltodextrin and CMC might cause it. The number of hydroxyl groups in both materials contributes to the solubility of anthocyanin powder because it can absorb water easily. Also, CMC could form and maintain the porosity or absorption properties of the powder after drying, which is easily dissolved by water (Abbasi and Azizpour, 2016; Ekpong et al., 2016). In this study, maltodextrin was used as a carrier agent to prevents the formation of the aggregates. Meanwhile, CMC was used as a foam stabilizer. According to the result in Table 3, the higher the egg white concentration used, the lower the powder solubility was obtained. It might be due to the protein denaturation during the drying process resulting in the formation of insoluble residue and decreased solubility level (Hardy and Jideani, 2017).
According to the viscosity analysis (Table 3), variations of egg white concentration did not affect the viscosity in all samples. Ekpong et al. (2016) have reported that various viscosity caused by the addition of maltodextrin. In addition, the use of CMC might have been related to the change of viscosity rather than maltodextrin, as $\mathrm{CMC}$ was a thickening agent. In this study, the concentration of maltodextrin and CMC were the same in all treatment. Thus the viscosities were the same in all samples.

Color properties are shown in Table 4. The brightness level of anthocyanin powders made from water extract was lower than ethanol extract. Contrary to that, the red and yellow color intensities of anthocyanin powders made from water extract were higher than ethanol extract. As the $\mathrm{pH}$ of anthocyanin extract from water extract (2.01) was lower than ethanol extract (3.21), the color of the powder from water extract becomes redder and darker since anthocyanin gives a red color in flavylium cation form at $\mathrm{pH} 1-3$. At $\mathrm{pH}>3$, the hydration of the flavylium cation was occurred, allowing the reduction of the red color intensity (Pham et al., 2019).

The concentration of the egg white did not affect the red and yellow color intensity in all powders. Meanwhile, the use of $20 \mathrm{~g} / 100 \mathrm{~mL}$ egg white significantly increased the brightness level in the powder made from water extract but did not affect the powder obtained from ethanol extract. These results are in line with Tan and Sulaiman (2020) for Hibiscus sabdariffa L. The white color of egg white and presenting of the air in the porous powder lead to the increase in brightness level.

Hue was used to defining the color. The hue values of powders were in the range of $14.32-20.05^{\circ}$, indicating that the colors of powders were a red color, as an angle

Table 4. Color properties of anthocyanin powders

\begin{tabular}{|c|c|c|c|c|c|c|}
\hline Solvent & Egg white $(\mathrm{g} / 100 \mathrm{~mL})$ & Brightness & Red & Yellow & Hue $\left({ }^{\circ}\right)$ & Chroma \\
\hline \multirow{2}{*}{$\begin{array}{l}\text { Water and } 2 \mathrm{~g} / 100 \mathrm{~mL} \text { citric } \\
\text { acid }\end{array}$} & 10 & $23.21 \pm 1.62^{c}$ & $23.16 \pm 1.03^{\mathrm{a}}$ & $8.47 \pm 0.99^{\mathrm{a}}$ & $20.05 \pm 1.33^{b}$ & $24.67 \pm 1.31^{\mathrm{b}}$ \\
\hline & 20 & $28.19 \pm 0.87^{b}$ & $22.52 \pm 0.78^{\mathrm{a}}$ & $7.88 \pm 0.25^{\mathrm{a}}$ & $19.28 \pm 0.06^{\mathrm{b}}$ & $23.86 \pm 0.81^{b}$ \\
\hline \multirow{2}{*}{$\begin{array}{l}\text { Ethanol and } 2 \mathrm{~g} / 100 \mathrm{~mL} \text { citric } \\
\text { acid }\end{array}$} & 10 & $33.47 \pm 0.45^{\mathrm{a}}$ & $16.93 \pm 0.18^{b}$ & $4.39 \pm 0.08^{b}$ & $14.53 \pm 0.13^{\mathrm{a}}$ & $17.49 \pm 0.20^{\mathrm{a}}$ \\
\hline & 20 & $32.48 \pm 1.70^{\mathrm{a}}$ & $17.36 \pm 0.98^{\mathrm{b}}$ & $4.42 \pm 0.08^{\mathrm{b}}$ & $14.32 \pm 1.01^{\mathrm{a}}$ & $17.92 \pm 0.93^{\mathrm{a}}$ \\
\hline
\end{tabular}

Values were expressed as mean \pm S.D. Different superscripts in the same column indicate significantly different at $p<0.05$ 
of 0 or $360^{\circ}$ represents red hue. Chroma was used to determine the degree of the hue. The red color intensity was increased as the increase in chroma value (Pathare et al., 2013).

\section{Conclusion}

Extraction using a water solvent with $2 \mathrm{~g} / 100 \mathrm{~mL}$ of citric acid was the most effective condition to obtain the highest total anthocyanin content. However, its total phenolic, flavonoid, and antioxidant activity were lower compared to others. Total anthocyanin content of foam mat dried purple sweet potato powder made from the citric acid-water extract was significantly higher than the powder made from the citric acid-ethanol extract. There was no effect in the total phenolic, flavonoid, viscosity, and yellowish-red color of the powder obtained from citric acid-water extract as the increase of egg white concentration. The use of $20 \mathrm{~g} / 100 \mathrm{~mL}$ egg white in both powders produced from citric acid-water and ethanol extracts resulted in higher total anthocyanins and solubilities than powders using $10 \mathrm{~g} / 100 \mathrm{~mL}$ egg white. The color of the powder obtained from citric acid-water extract had a lower brightness level and higher yellowish -red color intensity compared to the powder made from citric acid-ethanol extract. Based on the total anthocyanin content and its physical properties, the foam mat dried purple sweet potato anthocyanin powder produced by using $20 \mathrm{mg} / 100 \mathrm{~mL}$ of egg white from water extract added by $2 \mathrm{~g} / 100 \mathrm{~mL}$ of citric acid can be applied as a functional ingredient that contains antioxidant activity in the food product development.

\section{Conflict of interest}

The authors declare no conflict of interest.

\section{Acknowledgments}

Authors are thankful to Faculty of Biotechnology, Atma Jaya Catholic University of Indonesia, for providing facilities and financial support for this research work.

\section{References}

Abbasi, E. and Azizpour, M. (2016). Evaluation of physicochemical properties of foam mat dried sour cherry powder. LWT - Food Science and Technology, 68, 105-110. https://doi.org/10.1016/ j.lwt.2015.12.004

Albuquerque B.R., Pinela, J., Barros, L., Oliveira, M.B.P.P. and Ferreira, I.C.F.R. (2020). Anthocyanin -rich extract of jabutica epicarp as a natural colorant: Optimization of heat-and ultrasound-assisted extractions and application in a bakery product.
Food Chemistry, 316, 216314. https:// doi.org/10.1016/j.foodchem.2020.126364

Abou-Arab, A.A., Abu-Salem, F.M. and Abou-Arab, E.A. (2011). Physico-chemical properties of natural pigments (anthocyanin) extracted from roselle calyces (Hibiscus subdariffa). Journal of American Science, 7(7), 445-456.

Achir, N., Sinela, A., Mertz, C., Fulcrand, H. and Dornier, M. (2019). Monitoring anthocyanin degradation in Hibiscus sabdariffa extracts with multi-curve resolution on spectral measurement during storage. Food Chemistry, 271, 536-542. https://doi.org/10.1016/j.foodchem.2018.07.209

Aguidelo-Lavarde, L.M., Schebor, C. and Buera, M.P. (2013). Water content effect on the chromatic attributes of dehydrated strawberries during storage, as evaluated by image analysis. LWT - Food Science and Technology, 52(2), 857-862. https:// doi.org/10.1016/j.lwt.2012.06.022

Alam, M.S., Ashokkumar, B. and Siddiq, A.M. (2018). The density, dynamic viscosity and kinematic viscosity of protic polar solvents (pure and mixed systems) studies: A theoretical insight of thermophysical properties. Journal of Molecular Liquids, 251, 458-469. https://doi.org/10.1016/ j.molliq.2017.12.089

Alzeer, J. and Hadeed, K.A. (2016). Ethanol and its halal status in food industries: Review. Trends in Food Science and Technology, 58, 14-20. https:// doi.org/10.1016/j.tifs.2016.10.018

Arevström, L., Bergh, C., Landberg, R., Wu., RodriguezMateos, A., Waldenborg, M., Magnuson, A., Blanc, S. and Fröbert, O. (2019). Freeze-dried bilberry (Vaccinium myrtillus) dietary supplement improves walking distance and lipids after myocardial infarction: an open-label randomized clinical trial. Nutrition Research, 62, 13-22. https:// doi.org/10.1016/j.nutres.2018.11.008

Azwanida, N.N. (2015). A review on the extraction methods use in medicinal plants, principle, strength and limitation. Medicinal and Aromatic Plants, 4(3), 1000196.

Belwal, T., Dhyani, P., Bhatt, I.D., Rawal, R.S. and Pande, V. (2016). Optimization extraction conditions for improving phenolic content and antioxidant activity in Berberis asiatica fruits using response surface methodology (RSM). Food Chemistry, 207, $115-124$. https://doi.org/10.1016/ j.foodchem.2016.03.081

Buljat, A.M., Jurina, T., Tušek, A.J., Valinger, D., Kljusurić, J.S. and Bwnković, M. (2019). Applicability of foam mat drying process for 
production of instant cocoa powder enriched with lavender extract. Food Technology and Biotechnology, 57(2), 159-170. https:// doi.org/10.17113/ftb.57.02.19.6064

Cai, Z., Qu, Z., Lan, Y., Zhao, S., Ma, X., Wan, Q., Jing, P. and Li, P. (2016). Conventional, ultrasoundassisted, and accelerated-solvent extractions of anthocyanins from purple sweet potatoes. Food Chemistry, 197(A), 266-272. https://doi.org/10.1016/ j.foodchem.2015.10.110

Chen, C.C., Lin, C., Chen, M.H. and Chiang P.Y. (2019). Stability and quality of anthocyanin in purple sweet potato extracts. Foods, 8(9), 393. https:// doi.org/10.3390/foods 8090393

Cindrić, I.J., Kunštić, M., Zeiner, M., Stingeder, G. and Rusak, G. (2011). Sample preparation methods for the determination of the antioxidative capacity of apple juices. Croatica Chemica Acta, 84(3), 435438. https://doi.org/10.5562/cca1756

Dovene, A.K., Wang, L., Bokhary, S.U.F., Madebo, M.P., Zheng, Y. and Jin, P. (2010). Effect of cutting styles on quality and antioxidant activity of stored fresh-cut sweet potato (Ipomoea batatas L.) cultivars. Foods, 8(12), 674. https://doi.org/10.3390/ foods 8120674

Ekpong, A., Phomkong, W. and Onsaard, E. (2016). The effects of maltodextrin as a drying aid and drying temperature on production of tamarind powder and consumer acceptance of the powder. International Food Research Journal, 23(1), 300-308.

Fang, J. (2015). Classification of fruits based on anthocyanin types and relevance to their health effects. Nutrition, 31(11-12), 1301-1306. https:// doi.org/10.1016/j.nut.2015.04.015

Ferarsa, S., Zhang, W., Moulai-Mostefa, N., Ding, L., Jaffrin, M.Y. and Grimi, N. (2018). Recovery of anthocyanins and other phenolic compounds from purple eggplant peels and pulps using ultrasonicassisted extraction. Food and Bioproducts Processing, 109, 19-28. https://doi.org/10.1016/ j.fbp.2018.02.006

Gao, Y., Ma, S., Wang, M. and Feng, X.Y. (2017). Characterization of free, conjugated, and bound phenolic acids in seven commonly consumed vegetables. Molecules, 22(11), $1878 . \quad \mathrm{https}: / /$ doi.org/10.3390/molecules22111878

Giusti, M.M. and Wrolstad, R.E. (2005). Characterization and Measurement of Anthocyanins by UV-Visible Spectroscopy. In Wrolstad, R.E., Acree, T.E., Decker, E.A., Penner, M.H., Reid, D.S., Schwartz, S.J., Shoemaker, C.F., Smith, D. and Sporns, P. (Eds). Handbook of Food Analytical
Chemistry, p. 739-751. $1^{\text {st }}$ vol. Hoboken, US: John Wiley and Sons.

Guo, Y., Zhang, P., Liu, Y., Zha, L., Ling, W. and Guo, H. (2020). A dose-response evaluation of purified anthocyanins on inflammatory and oxidative biomarkers and metabolic risk factors in healthy young adults: A randomized controlled trial. Nutrition, 74, 110745. https://doi.org/10.1016/ j.nut.2020.110745

Halee, A., Supavititpatana, P., Ruttarattanamongkol, K., Jittrepotch, N., Rojsuntornkitti, K. and Kongbangkerd, T. (2018). Effect of solvent types and citric acid concentrations on the extraction of antioxidants from the black rice bran of Oryza sativa L. cv. Hom Nin. Journal of Microbiology, Biotechnology and Food Sciences, 8(2), 765-769. https://doi.org/10.15414/jmbfs.2018.8.2.765-769

Hardy, Z. and Jideani, V.A. (2017). Foam-mat drying technology: a review. Critical Reviews in Food Science and Nutrition, 57(12), 2560-2572. https:// doi.org/10.1080/10408398.2015.1020359

Haryanto, B. (2016). Pengaruh konsentrasi putih telur terhadap sifat fisik, kadar antosianin dan aktivitas antioksidan bubuk instan ekstrak kulit manggis (Garcinia mangostana L.) dengan metode foam mat drying. Jurnal Kesehatan, 7(1), 1-8. https:// doi.org/10.26630/jk.v7i1.112

He, X.L., Li, X.L., LV, Y.P. and He, Q. (2015). Composition and color stability of anthocyaninbased extract from purple sweet potato. Food Science and Technology, 35(3), 468-473. https:// doi.org/10.1590/1678-457X.6687

Iqbal, M.J., Abbas, A., Rafique, H., Nawaz, M.F. and Rasool, A. (2018). A review paper on foam-mat drying of fruits and vegetables to develop powders. MOJ Food Processing and Technology, 6(6), 465467. https://doi.org/10.15406/mojfpt.2018.06.00207

Jiang, T., Mao, Y., Sui, L., Yang, N., Li, S., Zhu, Z., Wang, C., Yin, S., He, J. and He, Y. (2018). Degradation of anthocyanins and polymeric color formation during heat treatment of purple sweet potato extract at different pH. Food Chemistry, 217, 497-504.

https://doi.org/10.1016/ j.foodchem.2018.07.141

Jivan, M.J., Yarmand, M. and Madadlou, A. (2014). Preparation of cold water-soluble potato starch and its characterization. Journal of Food Science and Technology, 51(3), 601-605. https://doi.org/10.1007/ s13197-013-1200-y

Jung, J.K., Lee, S.U., Kozukue, N., Levin, C.E. and Friedman, M. (2011). Distribution of phenolic compounds and antioxidative activities in parts of 
sweet potato (Ipomoea batata L.) plants and in home processed roots. Journal of Food Composition and Analysis, 24(1), 29-37. https://doi.org/10.1016/ j.jfca.2010.03.025

Lavelli, V. and Kerr, W. (2019). Moisture properties and stability of novel bioactive ingredients. In Galanakis, C.M. (Ed). Food Quality and Shelf Life, p. 33-54. United States: Academic Press. https:// doi.org/10.1016/B978-0-12-817190-5.00002-1

Levetin, E. and McMahon, K. (2012). Plants and Society. $6^{\text {th }}$ ed. New York: McGraw-Hill.

Li, H., Deng, Z., Zhu, H., Hu, C., Liu, R., Young, J.C. and Tsao, R. (2012). Highly pigmented vegetables: anthocyanin compositions and their role in antioxidant activities. Food Research International, 46(1), 250-259. https://doi.org/10.1016/ j.foodres.2011.12.014

Liu, X., Mu, T., Sun, H., Zhang, M. and Chen, J. (2015). Optimisation of aqueous two-phase extraction of anthocyanins from purple sweet potatoes by response surface methodology. Food Chemistry, 141 (3), 3034-3041. https://doi.org/10.1016/ j.foodchem.2013.05.119

Lu, L.Z., Zhou, Y.Z., Zhang, Y.Q., Ma, Y.L., Zhou, L.X., Li, L., Zhou, Z.Z. and He, T.Z. (2010). Anthocyanin extracts from purple sweet potato by means of microwave baking and acidified electrolysed water and their antioxidation in vitro. International Journal of Food Science and Technology, 45(7), 1378-1385. https:// doi.org/10.1111/j.1365-2621.2010.02271.x

Ma, Y., Feng, Y., Diao, T., Zeng, W. and Zuo, Y. (2020). Experimental and theoretical study on antioxidant activity of the four anthocyanins. Journal of Molecular Structure, 1204, 127509. https:// doi.org/10.1016/j.molstruc.2019.127509

Marinova, G. and Batchvarov, V. (2011). Evaluation of the methods for determination of the free radical scavenging activity by DPPH. Bulgarian Journal of Agricultural Science, 17(1), 11-24.

Martins, N., Roriz, C.L., Morales, P., Barros, L. and Ferreira, I.C.F.R. (2016). Food colorants: Challenges, opportunities and current desires of agro -industries to ensure consumer expectations and regulatory practices. Trends in Food Science and Technology, 52, 1-15. https://doi.org/10.1016/ j.tifs.2016.03.009

Meng, X.J., Tan, C. and Feng, Y. (2019). Solvent extraction and in vitro simulated gastrointestinal digestion of phenolic compounds from purple sweet potato. International Journal of Food Science and Technology, 54(10), 1-10. https://doi.org/10.1111/ ijfs. 14153

Mukherjee, P.K. (2019). Quality Control and Evaluation of Herbal Drugs: Evaluating Natural Products and Traditional Medicine. $1^{\text {st }}$ ed. Oxford: Elsevier. https://doi.org/10.1016/B978-0-12-813374-3.000016

Musilová, J., Bystrická, J., Árvay, J. and Harangózo, L. (2017). Polyphenols and phenolic acids in sweet potato (Ipomoea batatas L.) roots. Potravinarstvo Slovak Journal of Food Sciences, 11(1), 82-87. https://doi.org/10.5219/705

Nawi, N.M., Muhamad, I.I. and Marsin, A.M. (2015). The physicochemical properties of microwaveassisted encapsulated anthocyanins from Ipomoea batatas as affected by different wall materials. Food Science and Nutrition, 3(2), 91-99. https:// doi.org/10.1002/fsn3.132

Park, K.H., Kim, J.R., Lee, J.S., Lee, H. and Cho, K.H. (2010). Ethanol and water extract of purple sweet potato exhibits anti-atherosclerotic activity and inhibits protein glycation. Journal of Medicinal Food, 13(1), 91-98. https://doi.org/10.1089/ jmf.2009.1077

Pathare, P.B., Opara, U.L. and Al-Said. F.A. (2013). Colour measurement and analysis in fresh and processed foods: A review. Food and Bioprocess Technology, 6, 36-60. https://doi.org/10.1007/s11947 $-012-0867-9$

Pham, TN., Toan, T.Q., Lam, T.D., Vu-Quang, H., Vo, D.V.N., Vy, T.A. and Bui, L..M. (2019). Anthocyanins extraction from purple sweet potato (Ipomoea batatas (L.) Lam): The effect of $\mathrm{pH}$ values on natural color, presented at IOP Conference Series: Materials Science and Engineering, China, 2018. United Kingdom: IOP Publishing Ltd.

Peng, Y., Yan, Y., Wan., P., Dong, W., Huang, K., Ran, L., Mi, J., Zeng, X. and Cao, Y. (2020). Effects of long-term intake of anthocyanins from Lycium ruthenicum Murray on the organism health and gut microbiota in vivo. Food Research International, 130, 108952 . https://doi.org/10.1016/ j.foodres.2019.108952

Puspawati, G.A.K.D., Marsono, Y., Supriyadi and Armunanto, R. (2018). Comparison of sonication with maceration on antioxidant potency of anthocyanin and carotenoid of tamarillo (Solanum betaceaum Cav.). Agritech, 38(3), 304-312. https:// doi.org/10.22146/agritech.28959

Sinela, A., Rawat, N., Mertz, C., Achir, N., Fulcrand, H. and Dornier, M. (2017). Anthocyanins degradation during storage of Hibiscus sabdariffa extract and evolution of its degradation products. Food 
Chemistry, 214, 234-241. https://doi.org/10.1016/

j.foodchem.2016.07.071

Steed, L.E. and Truong, V.D. (2008). Anthocyanin content, antioxidant activity, and selected physical properties of flowable purple-fleshed sweet potato purees. Journal of Food Science, 73(5), 215-221. https://doi.org/10.1111/j.1750-3841.2008.00774.x

Sun, H., Zhang, P., Zhu, Y., Lou, Q. and He, S. (2018). Antioxidant and prebiotic activity of five peonidinbased anthocyanins extracted from purple sweet potato (Ipomoea batatas (L.) Lam.). Scientific Report, 8, 5018. https://doi.org/10.1038/s41598-01823397-0

Tan, S.L. and Sulaiman, R. (2020). Color and rehydration characteristics of natural red colorant of foam mat dried Hibiscus sabdariffa $\mathrm{L}$. powder. International Journal of Fruit Science, 20(1), 89105. https:// doi.org/10.1080/15538362.2019.1605557

Tavares, I.M.C., Sumere, B.R., Gómez-Alonso, S., Gomes, E., Hermosín-Gutiérrez, I., Da-Silva, R. and Lago-Vanzela, E.S. (2020). Storage stability of the phenolic compounds, color and antioxidant activity of jambolan juice powder obtained by foam mat drying. Food Research International, 128, 108750. https://doi.org/10.1016/j.foodres.2019.108750

Wang, J., Chi, Y., Cheng, Y. and Zhao, Y. (2018). Physicochemical properties, in vitro digestibility and antioxidant activity of dry-heated egg white protein. Food Chemistry, 246, 18-25. https://doi.org/10.1016/ j.foodchem.2017.10.128

Xu, J., Su, X., Lim, S., Griffin, J., Carey, E., Katz, B., Tomich, J., Smith, J.S. and Wang, W. (2015). Characterisation and stability of anthocyanins in purple-fleshed sweet potato P40. Food Chemistry, 186, 90-96. https://doi.org/10.1016/ j.foodchem.2014.08.123

Yaméogo, C.W., Bengaly, M.D. and Savadogo, A. (2011). Determination of chemical composition and nutritional values of Moringa oleifera leaves. Pakistan Journal of Nutrition, 10(3), 264-268. https://doi.org/10.3923/pjn.2011.264.268

Zhang, Q.W., Lin, L.G. and Ye, W.C. (2018). Techniques for extraction and isolation of natural products: a comprehensive review. Chinese Medicine, 13, 20. https://doi.org/10.1186/s13020018-0177-x

Zhu, F. and Sun, J. (2019). Physicochemical and sensory properties of steamed bread fortified with purple sweet potato flour. Food Bioscience, 30, 100411. https://doi.org/10.1016/j.fbio.2019.04.012 